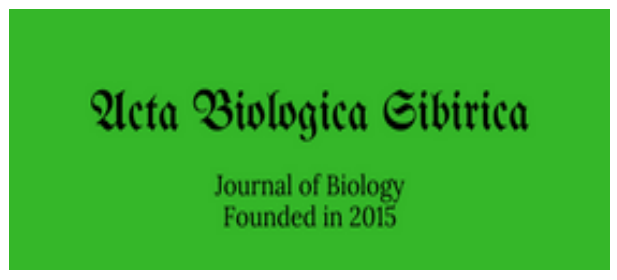

Altai State University

wWw.asu.ru

ISSN 2412-1908

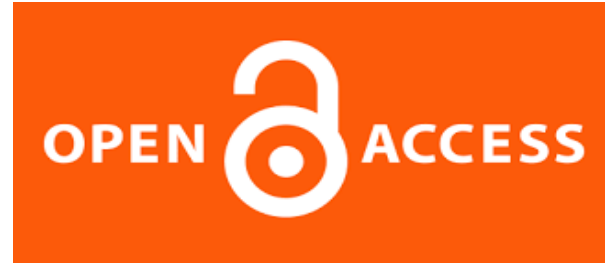

Acta Biologica Sibirica, 2017, 3(3), 97-110

\title{
Abyssnian pea (Lathyrus schaeferi Kosterin pro Pisum abyssinicum A. Br.) - a problematic taxon
}

\author{
O.E. Kosterin \\ Institute of Cytology and Genetics SB RAS, Acad. Lavrentyev ave. 10, Novosibirsk, 630090, Russia \\ Novosibirsk State University, Pirogova str. 2, Novosibirsk, 630090, Russia \\ e-mail: kosterin@bionet.nsc.ru
}

This is an English translation of a paper published in Russian (but with proper Latin formulations at taxonomical novelties to make them validly published) on March 15, 2017 in Vavilov Journal of Genetics and Plant Breeding, Vol. 22 (2): $158-169$. The Abyssinian pea (Pisum abyssinicum A. Br.), concerned in this review, is known from Ethiopia and Yemen, where it is cultivated along with the common pea (Pisum sativum L. subsp. sativum). The continuously reproduced notion of its possible spontaneous occurrence in the wild ascends to suppositions made in the XIX century and is not based on any actual data. P. abyssinicum is of practical interest owing to its extra early ripening and resistance to bacterial blight. Morphologically it is very similar to $P$. sativum but its crossability with it is bad as either seed or pollen parent. Traditionally this reproductive barrier was associated with karyological differences. The Abyssinian pea karyotype is variable as 1-2 reciprocal translocations were reported. At the same time there are accessions not differing from the standard karyotype of $P$. sativum with respect to reciprocal translocations, yet their crossability with the latter is very low and the pollen fertility of F1 and F2 hybrids is lowered. Data were reported on influence of the region of Linkage Group III, containing a gene known to participate in the conflict of nucleus and plastids in remote crosses of peas, on the pollen fertility of hybrids with abyssinian pea. With their karyological variability, the known accessions of the Abyssinian pea are very close to each other genetically, as they diverged just about 4000 years ago. The presence of alleles of molecular markers common with Pisum fulvum Sibth. et Smith on the one hand and with P. sativum L. subsp. elatius (Bieb.) Schmalh. on the other hand evidences in favour of an old hypotheses by L.I. Govorov that the Abyssinian pea originated from their spontaneous hybrid. This spontaneous cross may have taken place under cultivation, in Yemen or Afar Depression. A representative of $P$. sativum subsp. elatius was revealed, the F1 hybrids of which with the Abyssinian pea as a seed parent had fully fertile pollen. $P$. abyssinicum $\times P$. fulvum crosses provide the best hybrid seed outcome among remote crosses conducted, so that $P$. abyssinicum can be used as a 'bridge' for gene introgression from $P$. fulvum to $P$. sativum. Rather a high level of reproductive isolation of the Abyssinian pea from other representatives of the genus conforms the biological species concept, however the disposition of $P$. abyssinicum accessions as a small cluster among accessions of $P$. sativum subsp. elatius on molecular phylogeny reconstructions violates the phylogenetic species concept. Most authors assume the Abyssinian pea as a species, Pisum abyssinicum, some as a subspecies, P. sativum subsp. abyssinicum (A. Br.) Berger. Perhaps it would be most correct to consider it as a hybridogenic species. Because of the recent subsuming of the genus Pisum L. into the genus Lathyrus and with respect to the existing name Lathyrus abyssinicus A. Br. (a synonym of L. sativus L.), the Abyssinian pea was given a new name Lathyrus schaeferi (A. Braun) Kosterin (Vavilov Journal of Genetics and Breeding 21: 167. 2017) (pro Pisum abyssinicum A. Braun), in honour of Hanno Schaefer, who substantiated the revision of tribe Fabeae by molecular reconstruction of its phylogeny. The paper here translated contained new combinations of 
Kosterin, O.E. (2017). Abyssnian pea.... Acta Biologica Sibirica, 2017, 3(3), 97-110

Lathyrus sectio Pisum (L.) Kosterin (Vavilov Journal of Genetics and Breeding 21: 168. 2017) and Lathurus fulvus (Sibthrop et Smith) Kosterin (Vavilov Journal of Genetics and Breeding 21: 168. 2017).

Key words: Pisum abyssinicum; Pisum sativum; Pisum fulvum; Lathyrus schaeferi; pea; taxonomy; biological species concept; phylogenetic species concept; hybridogenic species; reciprocal translocations; conflict of nucleus and cytoplasm.

\section{Introduction}

This (the text below this paragraph) is an English translation of a review paper (Kosterin, 2017) published in Russian in Vavilov Journal of Genetics and Plant Breeding on March 15, 2017, in a printed hardcopy issue of the journal, ahead of its electronic version release (http://www.bionet.nsc.ru/vogis/download/taxon-21-02/05_Kosterin.pdf). That Russian paper contained some taxonomical novelties, furnished with all necessary Latin formulations and short explanations making them validly published. However, the reasons of those taxonomical solutions, cited below with reference to that paper, as well as a detailed presentation of the taxonomical situation, should be made available to an international reader in English. This motivated me to separately publish the English translation separately.

The Abyssinian pea - Pisum abyssinicum A. Br. (or, in other treatment, Pisum sativum L. subsp. abyssinicum (A. Br.) Berger), occurring in Yemen and Ethiopia along with the common pea P. sativum L. (Govoriv, 1937; Makasheva, 1979; Maxted, Kell, 2009), is a 'secondary relative'; of the latter as a closely related species of the same genus (Maxted, Kell, 2009), can be crossed with it, although not easily, and may serve a source of additional genetic diversity for selection of the common pea. Thus, it is resistant to the bacterial blight casued by Pseudomonas syringae pv. pisi without specificity to a 'race' of the parasite (Elvira-Recuenco et al., 2003; Hollaway et al., 2007). Attempts were already undertaken of introgression of this resistence to the common pea by crossing and its use in commercial cultivars (Elvira-Recuenco, 2000, cited by: [Maxted, Kell, 2009]; Elvira-Recuenco et al., 2003; Hollaway et al., 2007). However, literature concerning the Abyssinian pea is scanty and controversal that as such hampers both investigation of this narrow-ranged taxon and its potential practical use. The aim of this review is an attempt to overcome this annoying circumstance by compiling and discussing the knowledge on the Abyssinian pea contained in literature, with invoking of some own data.

In the last section of this paper devoted to taxonomical issue, the Latin name of the Abyssinan pea will have to be changed, and the author adopts this new name as correct. In order to correspond to the literature reviewed, however, before that section, the traditional names in the genus Pisum L. will be used for all pea taxa.

\section{Characters of Abyssinian pea}

Pisum abyssinicum A. Br. is a small and clear cut group of forms very similar to the common pea but even more to each other, so that even the monographer of the genus Pisum L., R.Kh. Makasheva (1979), did not split it into varieties and recognised only three subvarieties differing only in the seed cover coloration (mottled violet - subvar abyssinicum, dark violet - subvar. vavilovianum (Govorov) Makash., and greenish-grey - subvar. viridulogriseum (Govorov) Makash.). The Abyssinian pea is characterised by a small height of the main stem, a strong waxy bloom of young plants, which gives the foliage a silver hue, moderately dentate stipulae and leaflets, complete absence of anthocyanin pigmentation on the vegetative parts of a plant, small, rather pale flowers (Fig. 1, a) and an extremely early ripening (Govorov, 1937; Makasheva, 1979), with the early flowering even under long day conditions being determined by an unique allele of gene If (Weeden, 2007). According to our observations in a greenhouse, upon ripening of the seeds and withering of the main stem, a plant produces numerous basal branches, in size not less than the main stem, which start flowering and produce in sum more seeds than the main stem. This seems to be an adaptation to an arid climate aimed to utilise cases when the wet season, normally short, lasts for a longer time. In view of these peculiarities, the Abyssinian pea may be considered as a potential donor of early ripening genes for the common pea.

As follows from the botanical description of this taxon (Govorov, 1937; Makasheva, 1979), most of its characters, both qualitative and quantitative, do not extend beyond the limits of variation of the common pea (Pisum sativum L.). For instance, the first step of the key provided by R.Kh. Makasheva (1979, p. 56) for identification of the six subspecies of $P$. sativum, to which she also attributed the Abyssinian pea at a subspecies rank, as $P$. sativum subsp. abyssinicum (A. Br.) Berger, is as follows:

"1. Stem thin, branching at base, lower axillar branches of adult plant sprout at almost right angle to main stem. Upper part of a plant with four sympodial bundles. Only long internodes. Flowers small (1.8 cm or less). Seed coat moderately thick, height of cells of palisade epidermis + hypoderma mostly 90-130, rarely up to 180 mkm

+ Stem medium thick or thick, mostly not branching or weakly branching and mostly not at base, rarely branching at base under acute angle, sometimes at right angle but then seed coat thick (height of cells of palisade epidermis + hypoderma exceeds $180 \mathrm{mkm}$ ), finely grainy. Upper part of a plant with 6-11 sympodial bundles, rarely with 4 bundles but then sead coat finely grainy. Internodes from long to short. Flowers from medium-small $(2 \mathrm{~cm})$ to large $(3.5 \mathrm{~cm}) .5 e e d \mathrm{coat}$ of variable thickness (80)-90-180-250 mkm ... 4». 
In this first step of the key, some quantitative characters were mentioned with their continuum split very arbitrarily. For some of them some plants with the characters of the thesis were recommended to be considered at the antithesis if they have an additional qualitative character, the thick and gritty seed coat (provided by the dominant allele Gty), which is a characteristic of wild representatives of the species $P$. sativum (attributed by R.Kh. Makasheva (1979) to the subspecies $P$. sativum subsp. syriacum (Boiss et Noë) Berger and $P$. sativum subsp. elatius (Bieb.) Schmalh., but united into the same subspecies P. sativum subsp. elatius by N. Maxted and M. Ambrose (2001)). However, according to our data (Zaytseva et al., 2016), some of those wild representatives have thin, non-gritty seed coat, that disavows the first step of the key by R.Kh. Makasheva.
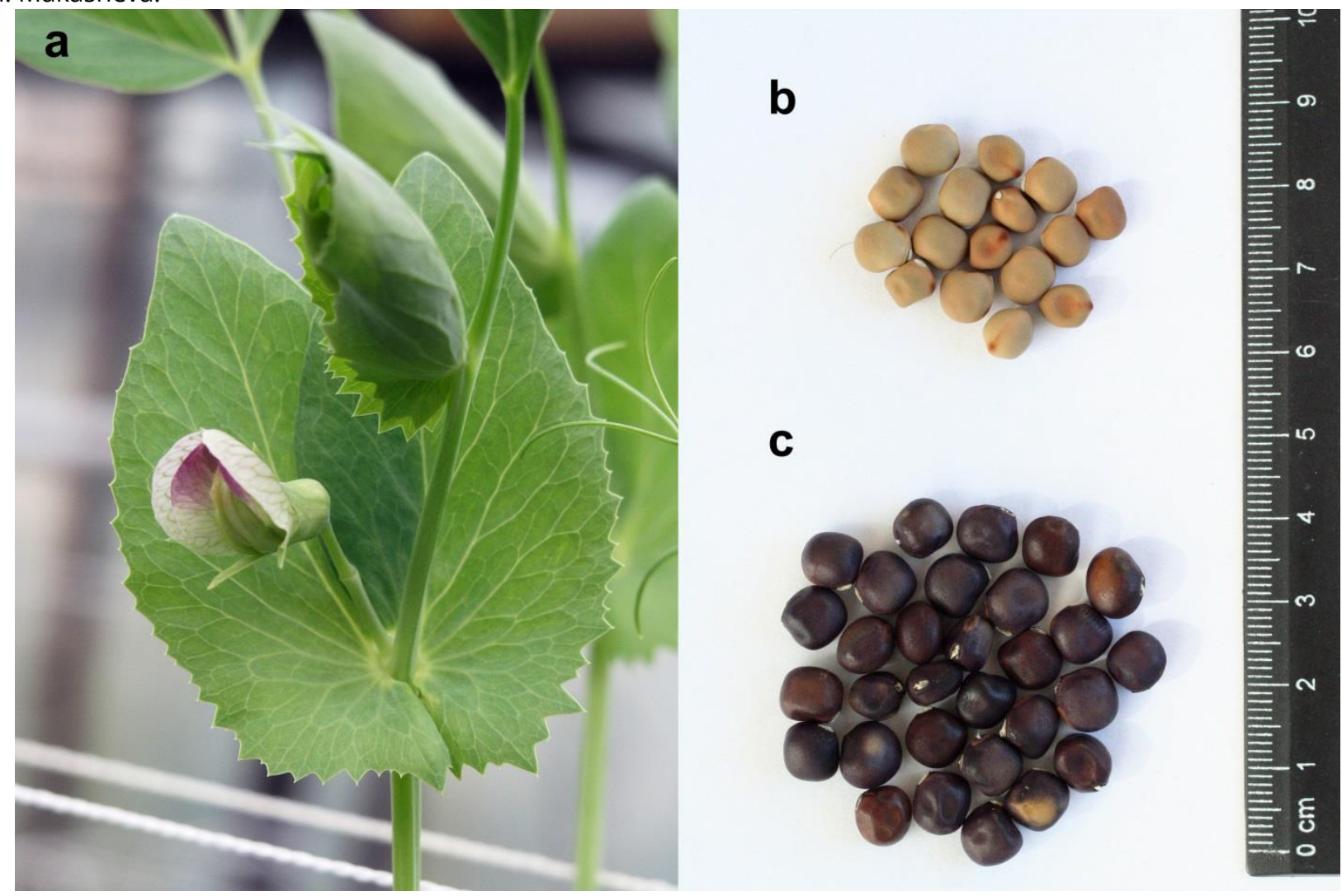

Fig. 1. Lathyrus schaeferi (A. Br.) Kosterin nom. nov. pro Pisum abyssinicum A. Br.

$a$ - the subapical apical node with a flower (accession VIR2759, Ethiopia); $b$ - seeds with phenotype u (accession WL1446); c - seeds with phenotype U (accession VIR2759).

In the mentioned key, the subspecies $P$. sativum subsp. abyssinicum follows the thesis and appears below, at step 2 , where it is opposed to other subspecies (ssp. asiaticum Govorov and ssp. transcaucasicum Makash.) by such characters as unipaired leaflets in the middle part of the plant, absence of the anthocyanin coloration at axils, stipulae dentate for $2 / 3$ of their margins, and "glossy seeds". However, the two former characters were mentioned also for some subspecies separated by step 1, which we do not consider adequate (see above). It seems that only the last mentioned character of the Abyssinian pea - the glossy seed surface - is not found in $P$. sativum (in other subspecies of $P$. sativum according to R.Kh. Makasheva) and can be called diagnostic (an autapomorphy). Note that the seeds of the Abyssinian pea are not globular but rather irregular, apressed from sides and slightly hollowed at the radicle, most frequently evenly violet-black (phenotype U, Fig. 1, c) but sometimes mottled violet or golden-grey (Fig. 1, b) (Makasheva, 1979).

\section{Cytogenetic peculiarities}

In spite of a strong similarity between the common and Abyssinian peas, crosses between them result in the first generation hybrids with very low fertility, that is there is a very strong reproductive barrier (Govorov, 1930; von Rosen, 1944; Drozd, 1965; Sobolev, Agarkova, 1975; Kosterin, Bogdanova, 2015). The reasons of this isolation are thought to be of a cytogenetical nature. Cytogenetic reasons would explain the high hybrid sterility indeed, as heterozygotes for chromosomal rearrangements face problems with euploid segregation of chromosomes in meiosis. However, they cannot explain low outcome of F1 hybrid seeds in crosses of the common and Abyssinian pea (Kosterin, Bogdanova, 2015), which should be associated either with some problems with simultaneous realisation of two versions of the genetic developmental programme combined in a hybrid embryo, or with prezygotic factors preventing zygote formation.

Cytogenetic differences between the Abyssinian and common pea are not so clear themselves. D. von Rosen (1944) found out that the Abyssinan pea karyotype has, as compared with the karyotype of the European cultivated pea, a reciprocal translocation and an inversion of one of the translocated chromosomes; he also supposed presence of other small rearrangements, inversions or deletions, affecting the lengths of the chromosome arms. F. Saccardo (1971) also 
found a reciprocal translocation in the Abyssinian pea. Basing on his genetic analysis, H. Lamprecht (1964) concluded that the Abyssinian pea had two independent reciprocal translocation. However, this report should be taken with caution as its author assumed the pea genetic map, first compiled by himself, in which some blocks of tightly linked genes were later proved to incorrectly united into linkage groups (for a review see Kosterin, 2015). By measuring the lengths of the chromosomal arms in hybrids of the Abyssinian pea with a line with a standard pea karyotype and with lines of the standard set of translocations (Lamm, Miravalle, 1959), C. Conicella and A. Errico (1990) supposed that both studied lines of $P$. abyssinicum most probably had pericentric inversions in chromosome 6 , the limits of inversions in the two lines not coinciding. One of those lines probably had also a deletion in chromosome 4 (which was shortened), but had no reciprocal translocations. In the other line, a reciprocal translocation involving chromosomes 3 and 4 was found by observation of cross-like structures in the meiosis I profase.

We face a considerable karyotype variation in the Abyssinian pea, by the way found in a single study (Conicella, Errico, 1990) that excludes artifacts resulted from possible difference of methods used by different researchers. It is important that one of the lines had no translocations as compared with the standard karyotype of $P$. sativum subsp. sativum and differed from it only by inversion and, possibly, a deletion. Such differences cannot be the reason of the low reproductive compatibility with the common pea, as among gametes produced by structural heterozygotes for inversions only few crossovers inside inversions are lethal. Indeed, chromosomal bridges were observed in anafase of meiosis I in hybrids between the Abyssinian and common pea (Sobolev, Agarkova, 1975), which pointed at the presence of dicentric fragments which result from crossing over inside inversions in meiosis I of structural heterozygotes. Thus, the reproductive barrier between the common and Abyssinian peas, as manifested by hybrid sterility, at least in part should have a non-cytogenetical nature.

\section{Range and cultivated status}

The abyssinian pea is known to be cultivated in Ethiopia and Yemen (Govorov, 1937; Makasheva, 1979; Maxted, Ambrose, 2001). It is noteworthy that diverse traditional pea landraces are cultivated in Ethiopia, the majority of which belong to the cultivated subspecies of the common pea, $P$. sativum subsp.sativum, and only few of those represent $P$. abyssinicum (Makasheva, 1979). This is in particular evidenced by a large collection of pea landraces collected in Ethiopia by N.I. Vavilov and preserved in N.I. Vavilov All Russian Institute of Plant Genetic Resources, studied by us earlier (Berdnikov et al., 1989; 1993). This circumstance sometimes results in wrong identifications, when traditional pea accessions from Ethiopia are attributed to the Abyssinian pea basing solely on its name rather than its characters.

Both old and recent literature contains groundless statements on existence of the Abyssinian pea in the wild. Such reports are most probably no more than suppositions and insufficiently grounded extrapolations, repeated by subsequent authors after their preceders. In his classical treatment of the genus Pisum for "Cultivated Flora of the U.S.S.R", L.I. Govorov provided controversal information about the Abyssinian pea. He spoke about it as a cultivated species: "It is necessary to recognise in the genus Pisum, along with the cultivated $P$. sativum and $P$. abyssinicum, 4 wild species: $P$. formosum (Stev.) Boiss., P. fulvum Sibth et Sm., P. elatius (MB.) Stev. and P. humile Boiss et Noë" (Govorov, 1937: p. 232). Further this author mentioned by the way its existence in a wild state: "In the montane areas of Abyssinia, where an endemic species $P$. abyssinivum exists in the wild state and cultivation, peculiar forms are more widely distributed, which should be attributed to $P$. sativum ssp. communae» (Ibidem: p. 243). Further in the text it becomes clear that existence of the Abyssinian pea in the wild is just a supposition made in mid. XIX century: "A. Richards (1847) put forward a supposition that $P$. abyssinicum is a wild form of Abyssinia. E. Chiovenda (1912) believes that these pea forms are among the most ancient ones involved into cultivation and only rarely occurring in a wild state" (Ibidem, p. 244). P.M. Zhukovskiy (1964) communicated indefinite information about the Abyssinian pea distribution: "grows in Yemen and Ethiopia in the mountains, is cultivated by local population". R.Kh. Makasheva (1979: p. 69) reported that it is "known in culture, rarely occurs in a wild state in the mountains at elevations up to 2,000 $\mathrm{m}$ a.s.I.". One can conclude that no specific information about finding of $P$. abyssinicum in a wild nature was published either in XIX, or in XX century. Thus, a notion on existence of the Abyssinian pea in the wild state is most probably a kind of a scientific myth.

It seemed as indications at findings of $P$. abyssinicum in a wild state appeared recently in a essential work by $\mathrm{N}$. Maxted and S.P. Kell (2009: p. 107), who claimed that the wild P. abyssinicum was collected in three localities in Ethiopia (in Tigrai, Welo and Arsi Provinces) and make a footnote reservation that "collections have also been made at other locations (mainly markets) in Ethiopia". Note that Welo (Wollo) and (Arsi) Arssi Provinces no more exist since 1995 - the former was divided between the current Amhara and Afar Provinces, the latter was included into Oromia Province. Figure 19 in the the cited work (Maxted, Kell, 2009) contains a map (with the province borders which existed before 1995) where these localities were pointed out. As the source of data the figure legend refers to SINGER database accessed on 18/07/2008 through GBIF portral, http://data.gbif.org/datasets/resource/1430. According to the personal communication by S.P. Kell, the data on the wild state of the Abyssinian pea were extracted from that base. The author of the present review checked the base and found out that it does not contain any data on a wild state of the accessions indicated. They belong to a group of accessions of the ICARDA collection with the range of numbers ICARDA-51495-ICARDA-51506, 'field numbers' 22770-22880, and exact coordinates doubtlessly retrieved with a GPS navigator. It is evident that they were collected by the same expedition and quite recently (no collector and dates being, however, indicated). The three localities of the 'wild Abyssinian pea" indicated in the map of fig. 19 in (Maxted, Kell, 2009) correspond to four accessions: ICARDA-51495, ICARDA- 51496 (both labelled as “ 
«41 km S of Nasareth, along road to Asela" [Oromia Province]), ICARDA-51497 ("Burahat, 41 km W of Adigrat" [Tigrai Province]), and ICARDA-51500 («3 km N of Korem") [Tigrai Province]). (Square brackets contain the author's explanations). From other accessions of the same range of numbers they differ only in that their labels do not contain the word "market", which is present in seven of the eight other accessions of this series, and the geographical information is not a town, as in the eight other accessions, but points at a certain distance from a town. Most probably, the authors cited (Maxted, Kell, 2009) used the following 'logic': if an accession was obtained at a marked it is cultivated, and if not at a market and beyond a town than it is wild, disregarding the obvious circumstance that cultures grow not on markets an in towns but in fields beyond them! (Note that, according to the author's own observations, the Ethiopian Upland is almost completely agricultirally explored, with fields covering most of its area). We see that the scientific myth of existence of the wild Abyssinian pea is so viable that continues to be supported even by prominent scientists.

\section{Hypotheses of origin}

Absence of any trustful information on the Abyssinian pea in the wild state rather sharpen than cancel the question of its origin. L.I. Govorov noted on this subject the following: "A more detailed study of material from South-West Arabia provides more arguments to consider these forms a peculiar independent species $P$. abyssinivum, endemic for Yemen and adventive in Abyssinia" (Govorov, 1937: p. 240). It would be difficult to disagree with this statement. The genus (or section) Pisum, as well as the entire tribe Fabeae, are of a Mediterranean origin, while the Ethiopian Upland resides in the African Subkingdom of the Paleotropical Floristic Kingdom (Takhtadjan, 1978), to where only few representatives of the tribe penetrate (Schaefer et al., 2012). According to the author's personal observations in August 2012, representatives of tribe Fabeae are generally absent from the Ethiopian Upland (only one species found for two weeks of fieldwork). At the same time, Arabia has a flora transitory from the Ethiopian to the Mediterranean, and could be the homeland of a special pea species. An exceptionally early ripening of the Abyssinian pea suggests its origin from regions with a very short period favourable for vegetation. This could quite be the arid Arabia, but also Afar (or Danakil) Depression over the Read Sea.

L.I. Govorov, however, put forward suppositions on the Abyssinian pea origin which seem much less substantiated. He believed that $P$. abyssinicum originated from a singular hybridisation of $P$. elatius and $P$. fulvum: "A possibility is not excluded ... that one initial hybrid complex was synthesised from these two species in the zone of their present range including Asia Minor, Transcaucasia, Iran and Syria with Palestine. From this complex ... the wild species $P$. humile doubtlessly originated. From the same cross an endemic species of the mountainous regions of Arabia, $P$. abyssinicum, originated, to spread later in the mountainous Abyssinia" (Govorov, 1937: p. 240). Further this author noted: "By morphological characters it $<P$. abyssinicum. - O. $K$. $>$ stands closer to $P$. fulvum; the exceptional early ripening also approaches it to the efemer $P$. fulvum <but $P$. fulvum is not an ephemer! $-O$. $K$. $>$. No doubt that $P$. fulvum took part in the synthesis of $P$. abyssinicum. Under influence of the subsequent mutations and crosses of $P$. abyssinicum with $P$. elatius or with the derivative ssp. asiaticum, with forms from Egypt (proles aegypticum). the diversity of other cultivated forms, widely distributed in mountainous regions of Abyssinia. ... There was influence of $P$. abyssinicum on formational process of peas of Central India. Here the synthesis went on mostly under influence of the Asian forms (ssp. asiaticum), but sereation of leaflets, a strong anthocyanin coloration of plants at the first phases of their growth, and also an early ripening give a ground to suppose the influence of the Arabian endem on the lea of India" (Govorov, 1937: p. 240).

All these bold suppositions were made because of assuming phylogenetic sense in such phenotypic characters as the early ripening, serration, anthocyanin pigmentation. Without more reliable phylogenetic markers this was understandable. Besides, L.I. Govorov stood on an implicit assumption that each of these characters could arise in evolution only once and its presence in the phenotype indicates that its initial carrier was among the ancestors. That is he completely excluded homoplasy - independent origin of the same characters because of independent mutations in the same or different genes. However for us it seems doubtless that all such characters are very flexible, depend on many genes, adaptively loaded (maybe except for the serration) and, as a consequence, are able of repeated changes in any direction in the course of evolution and hence are inapplicable for reconstruction of phylogenetic relationships.

\section{Abyssinian pea in view of molecular studies}

Modern molecular reconstructions of the phylogeny of the genus Pisum showed that all studied accessions of $P$. abyssinicum are genetically very close to each other (in a full correspondence with their external characters) and form a small and tight branch indise (!) the phylogenetic tree of P. sativum s.l. (Ellis et al., 1998; Vershinin et al., 2003; Zaytseva et al., 2012, 2015). The genetic homogeneity of this taxon probably evidences for a strong bottleneck effect in its prehistory, perhaps associated with a hybridisation event (Vershinin et al., 2003). This genetic homogeneity is contrasted to the above mentioned cytogenetic heterogeneity of this taxon (Lamprecht, 1964; Conicella, Errico, 1990), the reason of which is unclear. The time of divergence of accessions of $P$. abyssinicum from each other, that is the time of existence of their last common ancestor, was estimated as 4000 years ago.

T.H.N. Ellis et al. (1998) reasonably considered it to be a time of domestication of $P$. abyssinicum, taken place independently from $P$. sativum subsp. sativum, divergence of which had started 10000 years ago since the moment of its domestication. The estimation of the divergence time of the Abyssinian pea roughly coincides with the presumed dating of penetration of the Euroasian agricultural practice to Ethiopia. This time corresponds to the onset of the Middle Kingdom of Egypt. However, the time of divergence of the branch of $P$. abyssinicum as such from other representatives of the genus 
Kosterin, O.E. (2017). Abyssnian pea.... Acta Biologica Sibirica, 2017, 3(3), 97-110

Pisum is comparable to that of the branch of $P$. sativum subsp. sativum (Ellis et al., 1998). This could mean that the Abyssinian pea had diverged from the common pea earlier than it was domesticated. Note, however, that we speak on independent domestication of two different pea taxa rather than on independent origin of the practice of pea cultivation, or the very idea of agriculture. The Abyssinian pea resembles the common pea very much, is doubtlessly recognisable as a pea, and could have been recruited for cultivation as an admixture to the already cultivated $P$. sativum subsb. sativum, or could substitute it under deficite of seeds available for sawing. No data exist on the primary source of the $P$. abyssinicum recruited for cultivation.

At the same time, A.V. Vershinin et al. (2003) found out coincidence of a considerable share of alleles of the studied molecular markers in P. abyssinicum with those in P. fulvum. A later work by the same team (Jing et al., 2010) which undertook clustering of the genetic diversity of the genus with respect to the RBIP-markers (polymorphisu for retrotransposone insertions) supported the same conclusion: their subgroup 3.1, formed by accessions of $P$. abyssinicum, appeared equidistant from subgroups 3.2 ("P. elatius") and 3.4 ( $P$. fulvum), that reflects presence in the Abyssinian pea of comparable number of alleles common with either of these two taxa.

\section{Abyssinian pea as a hybridogenic species}

The above mentioned results have breathed a new life into the seemingly groundless and speculative hypothesis by L.I. Govorov (1937) about a hybrid nature of the Abyssinian pea. Since neither P. sativum subsp. elatius nor $P$. fulvum occur in the range of the Abyssinian pea, R. Jing et al. (2010) supposed that hybridisation between them took place in the western part of the Fertile Crescent (including present southern Turkey, Syria, Lebanon, Jordan, Israel), after which the hybrid form, representing a very small initial population, was taken into cultivation and brought to north-eastern Africa, where transformed into P. abyssinicum as we know it. This supposition looks quite plausible. The following reservations can be added to it:

1. Such a hybrid could attarct attention of an ancient farmer by its extreme early ripening allowing to yield crops in arid conditions.

2. The hypothesis considered implies that $P$. abyssinicum never existed in the wild state in its contemporary range (Yemen and Ethiopia).

3. At the same time there is no reason to believe that it were wild rather than cultivated forms of the common pea which participated in the initial hybridisation; that is the wild Abyssinian pea could have never existed at all. An ancient farmer already posessing the idea and habit of pea cultivation, originated from the initial pea domestication which formed $P$. sativum subsp. sativum, could involve into cultivation along or instead of it some local forms of $P$. sativum subsp. elatius, especially at shortage of seeds in cases of crop failure. Such involvement could take place through clogging of cultivated pea crop by wild forms. Also genotypes could be taken into cultivation which arose from spontaneous hybridisation, with a simultaneous selection among segregating hybrids for carriers of the domesticated syndrome, first of all for non-dehiscing pods but also other involved characters such as absence of seed dormancy and a non-gritty seed cover. With spreading of agriculture beyond the Fertile Crescent to less favourable conditions some of such hybrid genotypes could become advantageous. For instance, the arid Arabia would favour extra early ripening forms. Maybe they appeared in culture as a result of spontaneous hybridisation of $P$. sativum subsp. sativum and/or $P$. sativum subsp. elatius with $P$. fulvum, to give rise to the Abyssinian pea.

The hybrid nature of the Abyssinian pea may become a fixed fact or be rejected on the basis of the full genome studies which are still missing.

R. Jing et al (2010) reported that their cluster analysis has indicated the accessions of $P$. sativum subsp. elatius which are most related to the supposed progenitor of the Abyssinian pea. Unfortunately, the supplementary file containing information on the accessions studied is not accessible at the journal site, so this information is to be considered as unpublished.

In view of the hybrid theory of the Abyssinian pea origin it should be mentioned that all the four studied accessions of P. abyssinicum involved into the analysis of two paralogous histone H1 genes (Zaytseva et al., 2012, 2015) were found to have an identical unique allele of each of the two paralogs, not found beyond this taxon, that is specific to it. Also in three analysed accessions of $P$. abyssinicum, an unique nucleotide substitution was found in the plastidic spacer $p s b A$-trnH (Zaytseva et al., 2012, 2016). So the evolutionary branch of $P$. abyssinicum after its divergence has fixed unique (synapomorphic) alleles in some loci.

\section{Reproductive compatibility of the Abyssinian pea with other peas}

Representatives of $P$. abyssinicum were not yet involved into experiments on remote crossing with many pea forms altogether. In the hydroponic greenhouse of ICiG SB RAS, we carried out an extensive experiment on crossing of eight representatives of the genus Pisum L., including $P$. abyssinicum, according to the principle 'each with each and itself' (Kosterin, Bogdanova, 2015).

In the cited work, these accessions were proposed as a minimum basic set of genetic diversity of peas of the eastern Mediterranean. They were as follows:

1) WL2140 (=WL2029; =JI224, =PI560061; =Wt303), Israel, Jerusalem, Valley of Cross. A typical Pisum fulvum. 
Kosterin, O.E. (2017). Abyssnian pea.... Acta Biologica Sibirica, 2017, 3(3), 97-110

2) VIR2759 (=JI1556; =JI1869; =WL1491; =WL2042), Ethiopia. Pisum abyssinicum; classified by R.Kh. Makasheva (1979) as $P$. sativum subsp. abyssinicum var. vavilovianum Govorov.

3) L100 (=712 according to (Ben-Ze'ev, Zohary, 1973); =JI3273; =PI560069), Israel, $10 \mathrm{~km}$ S of Beer Sheva, wadi with loess sediment, a weed in a barley field. Pisum sativum subsp. elatius; originally classified by N. Ben-Ze'ev and D. Zohary (1973) as 'southern humile'.

4) VIR320, origin unknown (a contaminatnt to an accession from Palestine received by N.I. Vavilov in 1922 from E.W. Suttom (France). Pisum sativum subsp. elatius. A subline from a highly heterogeneous accession, classified by R.Kh. Makasheva (1979) as P. sativum subsp. syriacum (Boiss. et Noë) Berger var syriacum subvar unianulum Makasheva. Shows interesting peculiarities of reproductive compatibility with the cultivated pea (Bogdanova, Berdnikov, 2001; Bogdanova, Kosterin, 2006; Bogdanova, 2007; Bogdanova et al., 2009; 2012).

5) 721 (=L104; =JI3262; =PI560059), Israel, Mt. Carmel, 5 km NW of Zihon Yaakov, in maquis. Pisum sativum subsp. elatius; originally classified by N. Ben-Ze'ev and D. Zohary (1973) as Pisum elatius.

6) JI1794 (=716 according to (Ben-Ze'ev, Zohary, 1973)), Golan Heights, about 3 km NW of El-Quneitra, Tel Abu Nida, on volcanic ash. Pisum sativum subsp. elatius; classified by N. Ben-Ze'ev and D. Zohary (1973) as 'northern humile'.

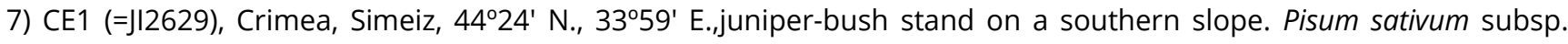
elatius.

8) WL1238 (=J173), testerline, Pisum sativum subsp. sativum. Homozygous for recessive alleles of many genes with morphological effect, posesses the standard pea karyotype (The Pisum-Genebank, 1984).

Detailed descriptions of the above enumerated accessions can be found in Supplementary Material 1 to the paper (Kosterin, Bogdanova, 2015). The above cited paper reported data on crosses with the cultivated subspecies $P$. sativum L. subsp. sativum with the seven other accessions.

Let us report in a generalised form our partly unpublished results on crosses of $P$. abyssinicum, represented by accession VIR2759 (Ethiopia, without more details) with other accessions. About 30 crosses were made in each combination (with the exception of $P$. fulvum with which as the maternal parent 112 crosses were made). We failed to obtain F1 hybrid only in two cross combinations, VIR2759 $\times$ L100 and VIR2759 $\times 721$, that is the Abyssinian pea as a maternal plant did not form any seeds as pollinated by both wild forms of $P$. sativum from southern Israel with which N. Ben-Ze'ev and D. Zohary (1973) worked. In all other cases, the outcome of viable hybrid seeds was very low as varying from 1 to 23 ones, while the efficiency of crosses, $e$, evaluated as the ratio of the number of the hybrid seeds formed to the number of flowers crossed (Kosterin, Bogdanova, 2014, 2015), varied from 0.01 to 0.76 . Note that the efficiency of crosses of accession VIR2759 to self in the same experiment appeared not much higher, 1.08 (Kosterin, Bogdanova, 2015), while in other crosses varied from 0.63 to 2.11 (Kosterin, Bogdanova, 2014). The mean number of seeds in intact pods of the same accession was estimated as $4.08 \pm 0.17$; here all pods on a plant were taken into account including those on lateral branches which usually have fewer seeds (Kosterin, Bogdanova, 2014). In Fig. 2 the values of the 'efficiency of crosses' parameter are schematically presented as classified to four conventional gradations. Statistically significant (at the significance level of $0.01 \%$ ) differences in the efficiency of reciprocal crosses was observed in crosses with four (WL2140, WL1238, L100, 721) of the seven accessions (including cases of absence of hybrids in one of the reciprocal directions), with varying direction of differences ( $P$. abyssinicum as a maternal or paternal parent). In view of the above mentioned hypothesis of the origin of $P$. abyssinicum from a spontaneous hybrid between $P$. fulvum and $P$. sativum subsp. elatius it is noteworthy that the maximum value of the crossing efficiency, 0.76 (23 seeds per 30 crosses), was observed in crosses $P$. abyssinicum $\times$ P. fulvum (VIR2759 $\times$ WL2140). This was noticed before, so that $P$. abyssinicum was even used as a 'bridge' for introgression of economically valuable genes from $P$. fulvum to $P$. sativum subsp. sativum, as it was more crossable to these taxa than them with each other (Forster et al., 1999).

Almost all F1 hybrids with P. abyssinicum appeared very scarcely fertile. The hybrids VIR2759 $\times$ JI1794 and VIR2759 $\times$ CE1 did not produce seeds at all, although produced flowers and numerous empty pods. Of 13 F1 hybrids VIR320 $\times 2759$ only 6 produced seeds (from one to six per plant); the only hybrid plant WL1238 $\times$ VIR2759 produced only two seeds. The largest number of seeds, on average $3.34 \pm 0.14$ per pod, were produced by hybrids L100 $\times$ VIR2759. The female fertility of reciprocal F1 hybrids of accession VIR2759 ( $P$. abyssinicum) with seven other accessions of the basic set is shown in Fig. 3 , where values of such a parametre as the mean number of seeds per pod are classified to four conventional gradations. Significant differences were observed in all pair of reciprocal hybrids but $P$. abyssinicum and $P$. fulvum, reciprocal hybrids between which produced about one seed per pod on average $(0.86 \pm 0.04$ in hybrids VIR2759 $\times$ WL2140 and 1.02 in the only hybrid plant WL2140 $\times$ VIR2759). (In case of accessions L100 and 721, hybrids in one of the two reciprocal directions were absent)

Fig. 4 shows schematically the values of pollen fertility (the proportion of viable pollen, evaluated under a microscope after acetocarmine staining according to Singh (2003)), in the obtained F1 hybrids of accession VIR2759 ( $P$. abyssinicum) with the seven other accessions of the basic set as classified into four conventional gradations coded by thickness of arrows. Some differences (in pollen fertility or existence of hybrids) were observed in five of the seven pairs of reciprocal crosses, with exception of the crosses with accessions CE1 (fertility about $1 / 4$ in both directions) and WL2140 (in both directions fertility about 1/2). The accession VIR2759 used as a maternal parent produced hybrids more fertile than the reciprocals in two cases (with WL1238 and J11794), and in two cases (with L100 and 721) the hybrids were obtained only in this direction. In general, the pattern of relative values of male fertility of the reciprocal hybrids (Fig. 4) resembles the pattern of female fertility as reflected by the parameter 'the mean number of seed per pod' (Fig. 3). However, by male fertility $P$. abyssinicum 
appeared more compatible (as the paternal parent) with accession 721, while by female fertility (as the maternal parent) with accession L100.

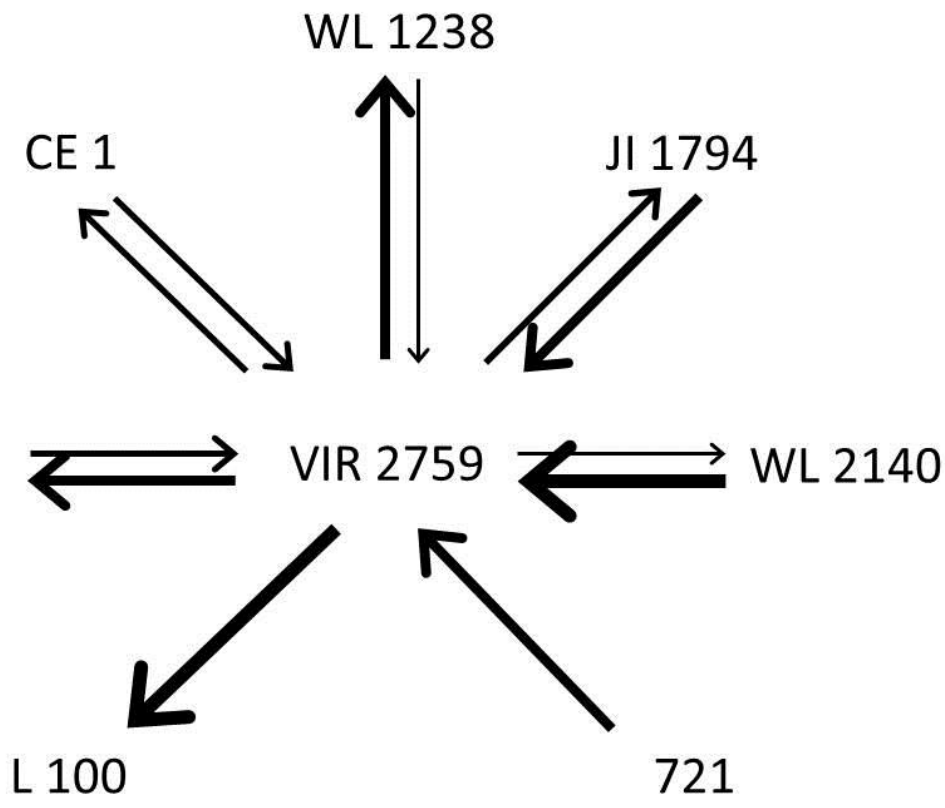

Fig. 2. Crossing efficiency (the mean number of hybrid seeds formed per cross) in reciprocal crosses of accession VIR2759 (L. schaeferi = P. abyssinicum) with seven other accessions from the basic set of pea forms of the East Mediterranean.

Arrow thicknesses indicate four conventional gradations of the crossing efficiency value: 1 , less than $0.10 ; 2,0.10$ to $0.25 ; 3,0.25$ to 0.50 ; and $4,0.5$ to 0.8 . Arrows are absent where no hybrid seeds were obtained in the corresponding direction of crosses.
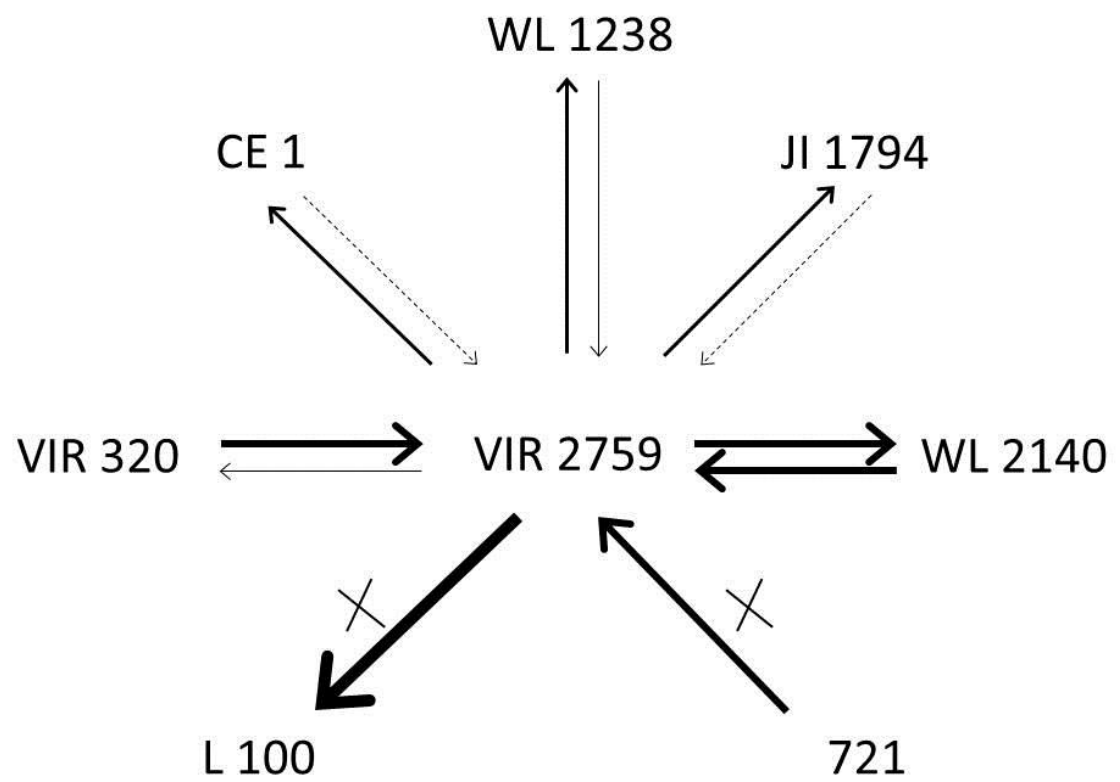

Fig. 3. The mean number of seeds per pod in reciprocal hybrids between accession VIR2759 (L. schaeferi $=\boldsymbol{P}$. abyssinicum) and seven other accessions from the basic set of pea forms of the East Mediterranean.

Arrow thicknesses indicates four gradations of the parameter: $-1,0.02-0.07 ; 2,0.3-0.7 ; 3,1.0-1.2$; and 4 , 3.34 (the only value). Dashed arrows indicate complete absence of seeds, $x-$ no hybrids formed in one of the reciprocal cross directions. 


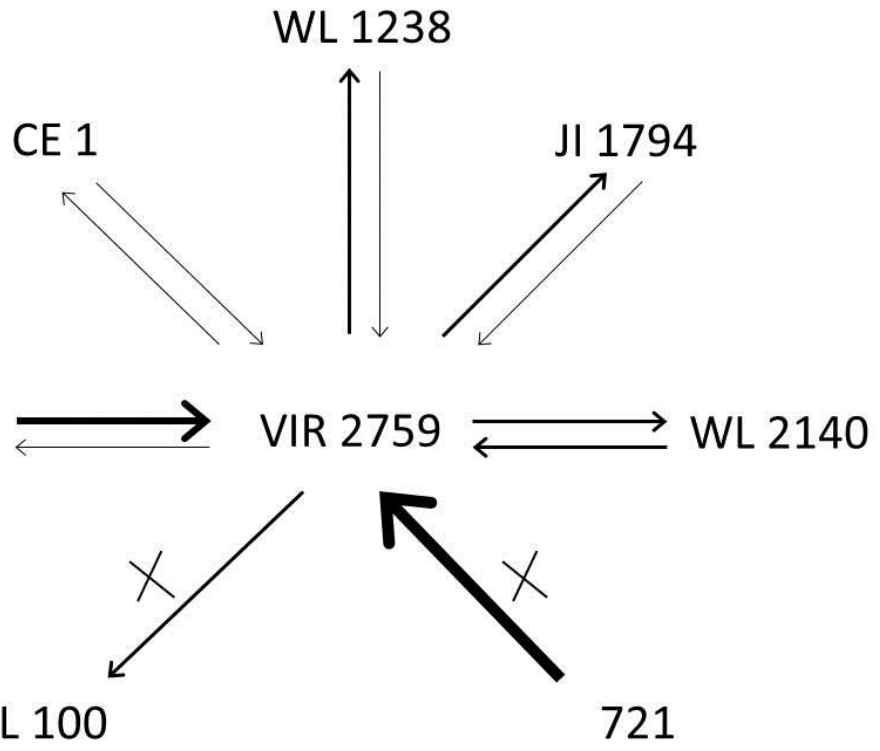

Fig. 4. Pollen fertility (the number of viable pollen grains related to the total number of grains) of reciprocal F1 hybrids between accession VIR2759 ( $L$. schaeferi $=P$. abyssinicum ) and seven other accessions from the basic set of pea forms of the East Mediterranean.

Arrow thicknesses indicate four gradations of fertility: 1, 1/4 (less than $33 \%$ ); 2, 1/2 (from 33 to 66 \%); 3, 3/4 (from 66 to $90 \%$ ); and 4, full fertility (more than $90 \%$; the only case). $\times$ - no hybrids formed in one of the reciprocal cross directions.

Especially interesting are cases of high (3/4 or more) male fertility indicating accessions most compatible with $P$. abyssinicum. These are hybrids VIR2759 $\times$ VIR320 and VIR2759 $\times 721$. In the latter crossing combination, the full pollen fertility was observed. This result is very important. First, it possibly indicates a representative of $P$. sativum subsp. elatius most related to $P$. abyssinicum, that is at a probable relative of that genotype which participated in formation of $P$. abyssinicum through hybridisation with $P$. fulvum, if $P$. abyssinicum is of a hybrid nature indeed. Second, this means that accessions VIR2759 and 721 do not differ in reciprocal translocations, otherwise the pollen fertility would not exceed 1/2 (Lamm, 1951; Lamm, Miravelle, 1959). Formally the pollen fertility of about $3 / 4$ in the hybrids of VIR2759 $\times 320$ evidences that these accessions also do not differ in reciprocal translocations. At the same time, the F1 hybrids WL1238 $\times$ VIR320 have the fully fertile pollen (Kosterin, Bogdanova, 2014) while the testerline WL1238 has the standard pea karyotype. From this it follows that the $P$. abyssinicum accession we used, VIR2759, also has no reciprocal translocations as compared to the standard pea karyotype. Hence, the partial pollen sterility differing in pairs of reciprocal F1 hybrids of $P$. abyssinicum with the cultivated subspecies $P$. sativum subsp. sativum and at least with some representatives of the wild subspecies $P$. sativum subsp. elatius has a non-karyological nature.

V.S. Bogdanova et al. (2014) analysed association of pollen fertility with an allelic state of locus Ph/C in F2 hybrids from the cross WL1072 (testerline of $P$. sativum) $\times$ VIR2759 (P. abyssinicum), that is on a background of the $P$. sativum cytoplasm. Carriers of the maternal allele of $P h / C$ (from $P$. sativum) showed some statistically significant excess of the viable pollen share as compared with heterozygotes and homozygotes for the paternal Ph/C alelle (89.9, 73.0 and $74.3 \%$, respectively). Note that these values substantially exceeded $50 \%$, thus excluding differences in reciprocal translocations between VIR2759 and the testerline WL1072, which also has the pea standard karyotype. The reciprocal cross did not produce the first generation progeny, so association of pollen fertility with an allelic state of Ph/C on the background of the cytoplasm from P. abyssinicum was analysed in a cross of VIR2759 with the above mentioned F2 hybrids, that is in hybrids VIR2759 $\times$ F2(WL1072 $\times$ VIR2759). Some statistically significant (at the $5 \%$ significant level) drop of viable pollen proportion was observed in heterozygotes for PhIC as compared to the homozygotes for the paternal (from P. abyssinicum) allele (64.4 against $73.2 \%$ ). So, a weak but statistically significant association was observed of the allelic state Ph/C with pollen fertility, which was higher in carriers of the allele of the same origin as the cytoplasm. The attention was focused to locus Ph/C, a convenient molecular marker on linkage group III, because of its tight linkage with gene Scs1 supposedly coding for the biotin carboxyl carrier protein in the plastidic, heteromeric form of the acetyl-coA carboxylase (Bogdanova et al., 2015), which is the main participant of the conflict of the nucleus and plastids from the nuclear side in crosses of line VIR320 $(P$. sativum subsp. elatius) with cultivated peas (Bogdanova et al., 2012, 2015) and, most probably, in other remote crosses in the genus Pisum (Bogdanova et al., 2014). Hence, pollen sterility in remote crosses with participation of $P$. abyssinicum at least in part is due to a nuclear-cytoplasmatic conflict 
Kosterin, O.E. (2017). Abyssnian pea.... Acta Biologica Sibirica, 2017, 3(3), 97-110

\section{Taxonomical status of Abyssinian pea}

Controvesy between the morphological similarity and scarce reproductive compatibility with the common pea leads to controversal taxonomical treatment of the Abyssinian pea. It was described (Braun, 1841) at a species rank and adopted in the same rank by many authors (Govorov, 1937; Ellis et al., 1998; Maxted, Ambrose, 2001; Vershinin et al., 2003; Kosterin, Bogdanova, 2008, 2015; Maxted, Kell, 2009; Jing et al., 2010; Kosterin et al., 2010; Zaytseva et al., 2012, 2015), while others considered it a subspecies of the common pea P. sativum subsp. abyssinicum (A. Br.) Berger (Berger, 1928; Makasheva, 1979), or an 'oecotype', that is a form without a definite taxonomical content (Lamprecht, 1963; Conicella, Errico, 1990). However, most recent authors incline to the species rank of the Abyssinian pea.

In case of taxonomical treatment of the Abyssinian pea, we as if face a contradiction between the biological and phylogenetic concepts of species. The very strong reproductive isolation from at least some forms of the common pea (Kosterin, Bogdanova, 2015) allows to consider it a species basing on the biological species concept by E. Mayr (1968), that was already discussed in our works (Kosterin, Bogdanova, 2008; 2015; Zaytseva et al., 2012). The position of the $P$. abyssinicum branch on reconstructed phylogenetic trees among branches referring to $P$. sativum, after ascribing the species rank to the former, makes the latter species paraphyletic, that in turn contradicts the phylogenetic (cladistic) classification. However this position of the Abyssinian branch is revealed in analyses of separate loci (Ellis et al., 1998; Zaytseva et al., 2012, 2015), most probably indeed inherited from $P$. sativum, while results of an analysis of many loci (Jing et al., 2010) convincingly evidence that the Abyssinian pea is a hybridogenic species originated through hybridisation of the common and tawny peas. We should specially note that according to the Note 1 to Article H3.3. of Appendix I to the 'International Code of Nomenclature for algae, fungi and plants (Melbourne Code)' (International Code..., 2012), "taxa that are believed to be of hybrid origin need not be designated as nothotaxa", so that there is no need in using the sign " $x$ " before the species epithet.

However, the recent taxonomical solutions in tribe Fabeae (Coulot, Rabaute, 2016) lead to a necessity of the Abyssinian pea to get another Latin name. A comprehensive work on molecular reconstruction of the tribe phylogeny based on six nucleotide sequences conducted by $\mathrm{H}$. Schaefer et al. (2012) revealed a picture incompatible with the traditional systematics. In particular, the branch Pisum-Vavilovia appeared inside genus Lathyrus L., so that the genera Pisum and Vavilovia A. Fedorov reside on the same branch with such species as Lathyrus gloeosperma Warb. et Eig., L. neurolobus Warb. et Eig. and L. nissolia L., traditionally attributed to sections Clymenium, Neurolobus and Nissolia, respectively. Thus, the genus Lathyrus (as well as the genus Vicia L.) in traditional sense appeared paraphyletic (at the same time the holophyly of the genus Pisum was corroborated). In order to bring the taxonomy in agreement to phylogeny, H. Schaefer et al. (2012) suggested to subsume the genera Pisum and Vavilovia into the genus Lathyrus, which would appear holophyletic as a result, however they abstained from publishing the corresponding nomenclatorial acts.

Such acts were published only in 2015 by P. Coulot and P. Rabaute (2016) in the fourth volume of their comprehensive 'Monographie de Leguminosae de France', where 10 pages are devoted to the taxa comprising the genus Pisum in the traditional sense. Actually these authors combined the genera Lathyrus L. and Pisum L., simultaneously published by Linnaeus and having the identical priority, and chose Lathyrus as the correct name of the united genus, acting in accordance with Article 11.5 of the 'International Code of Nomenclature of algae, fungi and plants (Melbourne Code)' (International Code..., 2012). Although the inclusion of the species of the genus Pisum into the genus Lathyrus changes the habitual classification substantially, the convincing argumentation by $\mathrm{H}$. Schaefer et al. (2012) makes to put up with such a taxonomical solution. In particular, the common pea, universally known as Pisum sativum L., gets the correct name Lathyrus oleraceus Lamarck, erected still by J.-B. Lamarck (1779) and based on another type.

However, the nomenclatorial treatment by P. Coulot and P. Rabaute (2016) not fully follows the acting 'International Code of Nomenclature of algae, fungi and plants (Melbourne Code)' (International Code..., 2012). These authors transferred the genus Pisum into the genus Lathyrus as the section Lophotropis Jaubert et Spach, for which they proposed a new combination Pisum L. sectio Lophotropis (Jaubert et Spach) H. Schaefer, Coulot et RabauteH.-F. Jaubert and E. Spach (1842) split the genus Pisum L. in two sections, Lophotropis Jaubert et Spach, including P. sativum L. (the type of the genus Pisum L.) and other peas, and Alophotropis Jaubert et Spach, including Pisum formosum (Stev.) Boiss. (later known as Vavilovia formosa (Stev.) A. Fed.). However, according to the Code Article 22.2, the section name Lophotropis Jaubert et Spach is not validly published, as it includes the type of the genus Pisum but its epithet does not repeat the name of the genus. As being not validly published, it could not be used as a basionym for a new combination (Articles 6.10 and 12.1), hence, Pisum L. sect. Lophotropis (Jaubert et Spach) H. Schaefer, Coulot et Rabaute is also not validly published. At the same time, the section name Alophotropis Jaubert et Spach was validly published, that, according to Articles $6.8,22.3$ and 32.3 , automatically created the autonym Pisum L. sect. Pisum (here written according to Article 22.1), validly published in 1842, for the section which, according to Article 7.6, was based on the same type, Pisum sativum L., as the genus Pisum L. This section included all taxa of the genus which were not attributed to section Alophotropis, which are all the taxa traditionally considered in the genus Pisum at least for the last half of the century, including species $P$. fulvum, $P$. sativum and $P$. abyssinicum, recognised ion the system by N. Maxted and M. Ambrose (2001).

This circumstance is favourable as it allows to preserve for peas the habitual name Pisum, at least at the section rank. Transfer of this section, including all taxa of peas (to which we do not attribute $V$. formosa) into the genus Lathyrus demanded a publication of a new combination, that was done in the initial, Russian version of this paper (Kosterin, 2017): 
Lathyrus sectio Pisum (L.) Kosterin (Vavilov Journal of Genetics and Breeding 21: 167. 2017).

Basionymum: Pisum L. sectio Pisum, autonymum creatum propter publicationem validam nominis Pisum L. sectio Alophotropis Jaubert et Spach (Illustr. PI. Orient. 1: 91. 1842) automatice proventum.

Typus: Pisum sativum Linnaeus (Sp. PI. 2:727. 1753).

Synonymum: Pisum Linnaeus (Sp. PI. 2:727. 1753).

Synonyma publicata invalida mente:

Pisum L. sectio Lophotropis Jaubert et Spach (Illustr. Pl. Orient. 1: 91. 1842);

Lathyrus L. sectio Lophotropis (Jaubert et Spach) H. Schaefer, Coulot et Rabaute (Monographie de Leguminosae de France. Tome 4. Bulletin de la Société Botanique du Centre-Ouest 46: 180, 854. 2016).

The Linnaeus' species Pisum sativum L. is retained to be the type of the section Lathyrus L. sect. Pisum L. (Articles 10.1, 10.3), in spite of the correct name of this species in the genus Lathyrus is now its heterotypic synonym Lathyrus oleraceus Lamarck.

P. Coulot and P. Rabaute (2016. P. 184, 854) also published new combinations for subspecies of the common pea occurring in France but, unfortunately, abstained from doing this for the taxa not occurring in France, although in their review they mentioned all taxa of at least some importance. In particular, in their 'Remarques' they mentioned also "Pisum sativum subsp. abyssinicum (A. Braun) Govorov (= Pisum jomardii Schrank)", in particular among the four cultivated taxa which they considered, perhaps after L.I. Govorov (1937), as resulting from secondary introgression with wild forms (Coulot, Rabaute, 2016: p. 184). The latter is true only for the Abyssinian pea (see above); besides, the synonymy with $P$. jomardii is erroneous here (Kosterin, Bogdanova, 2008; Zaytseva et al., 2016). However, no new combination has been proposed for the Abyssinian pea, and we had to fill this gap as well. The situation is complicated by the existence of the validly published name Lathyrus abyssinicus A. Br. ex Chiov., being a later synonym of Lathyrus sativus L. (Campbell, 1997). According to Article 53.1, the new combination in the genus Lathyrus with the final epithet based on the basionym Pisum abyssinicum A. Br. would be illegitimate as a later homonym. Hence for exclusion of homonymy, the Abyssinian pea when transferred to the genus Lathyrus should be given with a replacement name of the species rank, according to Articles 6.11, 11.4 41 and 53.1. It seemed logical to name the taxon in the honour of Hanno Schaefer, who is 'responsible' for this 'taxonomical revolution' with his molecular phylogenetic analysis (Schaefer et al., 2012). Hence the Abyssinian pea got the following Latin name:

Lathyrus schaeferi Kosterin (Vavilov Journal of Genetics and Breeding 21: 168. 2017), nomen novum pro

Pisum abyssinicum A. Braun (Bemerkungen über die Flora von Abyssinien. 1: 269. 1841), offertur ad vitare homonymian cum Lathyrus abyssinicus A. Br. ex Chiov. (Atti Soc. Ital. Progr. Sci. 17: 548. 1929), quando species considerata in genus Lathyrus L. mota sit.

With the transfer to the genus Lathyrus of the taxa considered ancestral for the Abyssinian pea, their correct names change as well. The wild subspecies of the common pea, used to be known as Pisum sativum L. subsp elatius, got the name Lathyrus oleraceus Lamarck subsp. biflorus (Rafinesque) H. Schaefer, Coulot et Rabaute (Coulot, Rabaute, 2016), with reference to the nomenclatorial correction earlier published by A. Soldano (1992). However, no new combination was published for the tawny pea, earlier known as Pisum fulvum Sibthrop et Smith, hence we publish it here:

Lathyrus fulvus (Sibthrop et Smith) Kosterin (Vavilov Journal of Genetics and Breeding 21: 168. 2017). Basionymum: Pisum fulvum Sibthrop et Smith (Prodr. Fl. Graec. 2: 62, 1813).

Lathyrus schaeferi Kosterin belongs to the section Lathyrus L. sect. Pisum (L.) Kosterin, hence according to Article 21A1, this name can be also written as Lathyrus (sect. Pisum L.) schaeferi Kosterin or Lathyrus (Pisum) schaeferi Kosterin.

As the use of Russian (and English) names is not codified, there is no obstacle for further using the traditional names 'горох абиссинский [gorokh abissinskiy]' ('Anyssinian pea'). The same refers to the Russian and English names of the common and tawny peas.

I would lake to remind that the acting 'International Code of Nomenclature for algae, fungi and plants (Melbourne Code)' (International Code.., 2011), as well as all previous versions of the Code, does not regulate scientific opinions concerning the volume and rank of taxa which, as well as any other scientific conclusions, are determined by convincingness and authoritativeness of scientific argumentation (ideally - by a consensus of scientists), but just determines the rules of operating names after an author made his taxonomical solution concerning the volume and rank of a taxon. Hence any author can retain the traditional taxonomical treatment of considering all peas in the genus Pisum L., being, however, aware that this treatment contradicts the phylogeny (Schaefer et al., 2012).

\section{Acknowledgments}

This study was supported by ICG State Budget Project 0324-2015-0005. The author is grateful to H. Schaefer for providing literature and valuable advice and to S.L. Nikolaev for translations into Latin. 
Kosterin, O.E. (2017). Abyssnian pea.... Acta Biologica Sibirica, 2017, 3(3), 97-110

\section{References}

Ben-Ze'ev, N., Zohary, D. (1973). Species relationship in the genus Pisum L. Israel J. Bot., 2, 73-91.

Berdnikov, V.A., Bogdanova, V.S., Rozov, S.M., Kosterin, O.E. (1989). Formirovanie mnogoobraziya genov gistona H1 v khode kul'turnoy evolyutsii gorokha [Formation of the diversity of histone $\mathrm{H} 1$ genes in the course of cultural evolution of pea]. Vavilovskoe nasledie v sovremennoy biologii [Vavilovian Heritage in Contemporary Biology]. Moscow: Nauka Publ., 72-89. (in Russian)

Berdnikov, V.A., Bogdanova, V.S., Rozov, S.M., Kosterin, O.E. (1993). Geographic patterns of histone H1 allelic frequencies formed in the course of Pisum sativum L. (pea) cultivaion. Heredity, 71, 199-209. DOI 10.1038/hdy.1993.125.

Berger, A. (1928). Systematic botany of peas and their allies. The Vegetables of New York. Vol. 1. Part 1. Peas of New York. Albany: J.B. Lyon Company.

Bogdanova, V.S. (2007). Inheritance of organelle DNA markers in a pea cross associated with nuclear-cytoplasmic incompatibility. Theor. Appl. Genet., 114, 333-339. DOI 10.1007/s00122-006-0436-6.

Bogdanova, V.S., Berdnikov, V.A. (2001). Observation of the phenomenon resembling hybrid dysgenesis in a wild pea subspecies Pisum sativum ssp. elatius. Pisum Genet., 33, 5-8.

Bogdanova, V.S., Kosterin, O.E. (2006). A case of anomalous chloroplast inheritance in crosses of garden pea involving an accession of wild subspecies. Doklady Akademii nauk = Reports of the Russian Academy of Sciences, 406, 256-259. DOI 10.1134/S0012496606010121. (in Russian)

Bogdanova, V.S., Galieva, E.R., Kosterin, O.E. (2009). Genetic analysis of nuclear-cytoplasmic incompatibility in pea associated with cytoplasm of an accession of wild subspecies Pisum sativum subsp. elatius (Bieb.) Schmalh. Theor. Appl. Genet., 118, 801-809. DOI 10.1007/s00122-008-0940-y.

Bogdanova, V.S., Galieva, E.R., Yadrikhinskiy, A.K., Kosterin, O.E. (2012). Inheritance and genetic mapping of two nuclear genes involved in nuclear-cytoplasmic incompatibility in peas (Pisum sativum L.). Theor. Appl. Genet., 124, 15031512. DOI 10.1007/s00122-012-1804-z.

Bogdanova, V.S., Kosterin, O.E., Yadrikhinskiy, A.K. Wild peas vary in their cross-compatibility with cultivated pea (Pisum sativum subsp. sativum L.) depending on alleles of a nuclear-cytoplasmic incompatibility locus. Theor. Appl. Genet., 127, 1163-1172. DOI10.1007/s00122-014-2288-9.

Bogdanova, V.S., Zaytseva, O.O., Mglinets, A.V., Shatskaya, N.V., Kosterin, O.E., Vasiliev, G.V. (2015). Nuclear-cytoplasmic conflict in pea (Pisum sativum L.) is associated with nuclear and plastidic candidate genes encoding Acetyl-CoA carboxylase subunits. PLOS ONE, 10, e0119835. http://dx.doi.org/10.1371/journal. pone.0119835.

Braun, A. (1841). Bemerkungen über die Flora von Abyssinien. Flora Oder Allgemeine Botahische Zeitung, 1, 257-288.

Campbell, C.G. (1997). Grass Pea, Lathyrus sativus L. Rome: International Pland Genetic Resource Institute, 1997.

Conicella, C., Errico, A. (1990). Karyotpe variations in Pisum sativum ect. abyssinicum. Caryologia, 43, 87-97. http://dx.doi.org/10.1080/0008.7114.1990.10796989.

Coulot, P., Rabaute, P. (2016). Monographie de Leguminosae de France. 4. Tribus des Fabeae, des Cicereae et des Genisteae. Bulletin de la Société Botanique du Centre-Ouest, 46, 1-902.

Drozd, A.M. (1965). Remote crosses in peas. Trudy po prikl. botan., genet., and selektsii = Bull. Appl. Bot., Genet. Plant Breeding, 37, 130-146. (in Russian)

Ellis, T.H.N., Poyser, S.J., Knox, M.R., Vershinin, A.V., Ambrose, M.J. (1998). Polymorphism of insertion sites of Ty1-copia class retrotransposons and its use for linkage and diversity analysis in pea. Mol. Gen. Genet., 260, 9-19. DOI 10.1007/PL00008630.

Elvira-Recuenco, M., Bevan, J.R., Taylor, J.D. (2003). Differential responses to pea bacterial blight in stems, leaves and pods under glasshouse and field conditions. Eur. J. Plant Pathol., 109, 555-564. DOI 10.1023/A:1024798603610.

Forster, C., North, H., Afzal, N., Domone, C., Hornostaj, A., Robinson, D.S., Casey, R. (1999). Molecular analysis of a null mutant for pea (Pisum sativum L.) seed lipoxygenase-2. Plant Mol. Biol., 39, 1209-1220. DOI 10.1023/A:1006173313548.

Govorov, L.I. (1930). Peas of Abyssinia. Trudy po prikl. botan., genet., and selektsii = Bull. Appl. Bot., Genet. Plant Breeding, 24, 399-431. (in Russian)

Govorov, L.I. (1937). Kulturnaya Flora SSSR [Cultivated flora of the USSR]. T.IV. Zernovye bobovye [Vol. 4. Grain legumes]. Moscow, State Publishing House of State Farm and Collective Farm Literature, IV, 229-336. (in Russian)

Hollaway, G.J., Bretag, T.W., Price T.V. (2007). The epidemiology and management of bacterial blight (Pseudomonas syringae pv. pisi) of field pea (Pisum sativum) in Australia: a review. Aust. J. Agric. Res., 58, 1086-1099. http://dx.doi.org/10.1071/AR06384.

International Code of Nomenclature for Algae, Fungi, and Plants (Melbourne Code). (2012). Oberreifenberg: Koeltz Scientific Books.

Jaubert, H.-F., Spach, E. (1842). Illustrationes Plantarum Orientalium. Tomus 1. Parisiis: Roret bibliopolam.

Jing, R., Vershinin, A., Grzebota, J., Shaw, P., Smýkal, P., Marshall, D., Ambrose, M.J., Ellis, T.H.N., Flavell, A.J. (2010). The genetic diversity and evolution of field pea (Pisum) studied by high throughput retrotransposon based insertion polymorphism (RBIP) marker analysis. BMC Evol., Biol., 10, 44. DOI 10.1186/1471-2148-10-44. 
Kosterin, O.E. (2017). Abyssnian pea.... Acta Biologica Sibirica, 2017, 3(3), 97-110

Kosterin, O.E. (2017). Abyssinian pea (Lathyrus schaeferi Kosterin nom. nov. pro Pisum abyssinicum A. Br.) is a problematic taxon. Vavilovskii Zhurnal Genetiki $i$ Selektsii = Vavilov Journal of Genetics and Breeding, 21, 158-169. DOI 10.18699/VJ17.234

Kosterin, O.E., Bogdanova, V.S. (2008). Relationship of wild and cultivated forms of Pisum L. as inferred from an analysis of three markers, of the plastid, mitochondrial and nuclear genomes. Genet. Res. Crop. Evol., 55, 735-755. DOI 10.1007/s10722-007-9281-y.

Kosterin O.E., Bogdanova, V.S. (2014). Efficiently of hand pollination in different pea (Pisum) species and subspecies. Ind. J. Genet. Plant Breeding., 74, 50-55. DOI 10.5958/j.0975-6906.74.1.007.

Kosterin, O.E. (2016). Under the reign of the Pea King (the difficult fate of the first genetical object. // Russian Journal of Genetics: Applied Research, 19., 13-26. DOI 10.1134/S2079059716010081

Kosterin, O.E., Bogdanova, V.S. (2015). Reciprocal compatibility within the genus Pisum L. as studied in F1 hybrids: 1. Crosses involving P. sativum L. subsp. sativum. Genet. Resour. Crop Evol., 62, 691-709. DOI 10.1007/s10722-014-0189-z.

Kosterin, O.E., Zaytseva, O.O., Bogdanova, V.S., Ambrose, M. (2010). New data on three molecular markers from different cellular genomes in Mediterranean accessions reveal new insights into phylogeography of Pisum sativum L. subsp. elatuis (Beib.) Schmalh. Genet. Res. Crop. Evol., 57, 733-739. DOI 10.1007/s10722-009-9511-6.

Lamarck, J.B. de. (1779). Flore Françoise, ou Description Succinte de Toutes des Plantes qui Croiffent Naturellement en France. Paris.

Lamm, R. (1951). Cytogenetical studies on translocations in Pisum. Hereditas, 37, 356-372. DOI 10.1111/j.16015223.1951.tb02899.x.

Lamm, R., Miravalle, R.J. (1959). A translocation tester set in Pisum. Hereditas, 45, 417-440. DOI 10.1111/j.16015223.1959.tb03059.x.

Lamprecht, H. (1963). Zur Kenntnis von Pisum arvense L. oect. abyssinicum Braun, mit genetischen und zytologischen Ergebnissen. Agri. Hort. Genet., 21, 35-55.

Lamprecht, H. (1964). Partielle sterilitat und chromosomenstruktur bei Pisum. Agri. Hort. Genet., 22, 56-138.

Makasheva, R.Kh. (1979). Kul'turnaya flora SSSR [Cultivated Flora of the USSR]. T. IV. Zernovye bobovye kul'tury [Grain legumes]. Ch.1. Gorokh [Part 1. Pea]. Leningrad: Kolos (in Russian)

Maxted N., Ambrose M. (2001). Peas (Pisum L.). Eds. N. Maxted, S.J. Bennett. Plant Genetic Resources of Legumes in the Mediterranean Current Plant Science and Biotechnology in Agriculture. Dordrecht: Kluwer Acad. Publ., 39, $181-190$.

Maxted N., Kell S.P. (2009). Establishment of a global network for the in situ conservation of crop wild relatives: status and needs. FAO Commission on Genetic Resources for Food and Agriculture. Rome. DOI 10.1023/B:BIOC.0000011719.03230.17.

Mayr, E. (1966). Animal species and evolution. Cambridge, MA: The Belknap Press of Harvard University Press.

Rosen von, D. (1944). Artkeuzungen in der gattung Pisum. insbesondere zwischen $P$. sativum L. und $P$. abyssinicum Braun. Hereditas, 30, 261-392.

Saccardo, F. (1971). Crosses among Pisum species. Pisum Newslett., 3, 38.

Schaefer, H., Hechenleitner, P., Santos-Guerra, A., Menezes, de Sequeira M., Pennington R.T., Kenicer G., Carine M.A. (2012). Systematics, biogeography, and character evolution of the legume tribe Fabeae with special focus on the middleAtlantic island lineages. BMC Evol. Biol., 12, 250. DOI 10.1186/1471-2148-12-250.

Singh, R.J. (2003). Plant Cytogenetics. Boca Raton: CRC Press.

Sobolev, N.A., Agarkova, S.N. (1975). Otdalennaya gibridizatsiya v rode Pisum L. [Remote Hybridisation in the Genus Pisum L.] Genetika i selektsiya gorokha [Pea genetics and breeding]. Novosibirsk, Nauka Publ., Siberian Branch, 141-160. (in Russian)

Soldano, A. (1992). Riproposizione di taxa sottospecifici prioritari dovuti a botanici italiani. Natura Bresciana (Ann. Mus. Civ. Sci. Nat., Brescia), 27(1990-1991), 51-56.

Takhtadzhyan, A.L. (1978). Floristicheskie oblasti Zemli [Floristic Regions of the Earth]. Leningrad: Nauka Publ. (in Russian)

The Pisum-Genebank. (1984). Origin Listing of Weibullsholm collection. Landscrona: Weibullsholm Plant Breeding Institute.

Vershinin, A.V., Allnutt, T.R., Knox, M.R., Ambrose, M.J. (2003). Transposable elements reveal the impact of introgression, rather than transposition, in Pisum diversity, evolution, and domestication. Mol. Biol. Evol., 20, $2067-2075$. DOI 10.1093/molbev/msg220.

Weeden, N.F. (2007). Genetic changes accompahying the domestication of Pisum sativum: is there a common genetic basis to the 'domestication syndrome' for legumes? Ann. Bot., 100, 1017-1025. DOI 10.1093/aob/mcm122.

Zaytseva, O.O., Bogdanova, V.S., Kosterin, O.E. (2012). Phylogenetic reconstruction at the species and intraspecies levels in the genus Pisum (L.) (peas) using a histone H1 gene. Gene, 504, $192-202$. http://dx.doi.org/10.1016/j.gene.2012.05.026.

Zaytseva, O.O., Gunbin, K.V., Mglinets, A.V., Kosterin, O.E. (2015). Divergence and population traits in evolution of the genus Pisum L. as reconstructed using genes of two histone $\mathrm{H} 1$ subtypes showing different phylogenetic resolution. Gene, 556, 235-244. ttp://dx.doi.org/10.1016/j.gene.2014.11.062.

Zaytseva, O.O., Bogdanova V.S., Mglinets A.V., Kosterin O.E. (2017). Refinement of the collection of wild peas (Pisum L.) and search for the area of pea domestication with a deletion in the plastidic psbA-trnH spacer. Genet. Resour. Crop. Evol., 64, 1417-1430. DOI 10.1007/s10722-016-0446-4. 
Zhukovskiy, P.M. (1964). Kul'turnye rasteniya i ikh sorodichi: sistematika, geografiya, ekologiya, proiskhozhdenie, ispol'zovanie [Cultivated plants and their relatives: taxonomy, geography, ecology, origin, and use]. Moscow: Kolos (in Russian)

\section{Citation:}

Kosterin, O.E. (2017). Abyssnian pea (Lathyrus schaeferi Kosterin pro Pisum abyssinicum A. Br.) - a problematic taxon. Acta Biologica Sibirica, 3 (3), 97-110.

Submitted: 27.06.2016. Accepted: 24.08.2017

crossref http://dx.doi.org/10.14258/abs.v3i3.3621 